\title{
Rhamnolipid Biosurfactants Produced by Pseudomonas Species
}

\author{
Banu Kaskatepe ${ }^{\mathbf{1}^{*}}$, Sulhiye Yildiz ${ }^{\mathbf{1}}$. \\ ${ }^{1}$ Ankara University, Faculty of Pharmacy, Department of Pharmaceutical Microbiology, Ankara/Turkey
}

\begin{abstract}
Surfactants are chemical products widely used in our daily life in toothpaste and other personal hygiene and cosmetic products, and in several industries. Biosurfactants are surfactants of biological origin that can be produced by microorganisms and have many advantages, such as low toxicity and high biodegradability, compared to synthetic counterparts. Unfortunately, high production costs limit the use of biosurfactants. Low-cost production is the most important factor for biosurfactants to be able to compete in the global market place. This review presents general information on rhamnolipid biosurfactant produced by Pseudomonas species, as well as on their production and applications. In addition, industrial products and their wastes used for rhamnolipid production are reviewed in detail based on recent studies.
\end{abstract}

Key words: application of rhamnolipid, biosurfactant, Pseudomonas spp., rhamnolipid

\footnotetext{
${ }^{1}$ Authors for correspondence: bkaskatepe@ ankara.edu.tr
} 


\section{INTRODUCTION}

Surfactants, or surface-active agents, are compounds that reduce the surface and interfacial tension between liquids or a liquid and a solid. Surfactants are chemically synthesized amphiphilic compounds containing both hydrophobic and hydrophilic groups. Biosurfactants are surfactants of biological origin, produced by microorganisms, and an increasing emphasis has been given to them recently due to their outstanding features, such as low toxicity, biodegradability, selectivity, and specific activity at extreme conditions (temperature, $\mathrm{pH}$, salinity, etc.). However, production costs of biosurfactants prevent them from competing with their synthetic counterparts. The use of cheaper substrates is the most important production factor in this competitive environment, and therefore current biosurfactant studies have been focused on increasing the yield and reducing the cost of production. Biosurfactants can be produced from industrial wastes, which means that cheaper production is possible. Besides, using wastes reduces their polluting effects on nature. Biosurfactants are categorized, mainly on the basis of their chemical composition, into glycolipids, lipopeptides, fatty acids, polysaccharide-protein complexes, peptides, phospholipids, and neutral lipids (Cooper and Goldenberg 1987). Rhamnolipids are the best known glycolipid biosurfactants and effective compounds with one or two molecules of $\beta$-hydroxydecanoic acid (Desai and Banat 1997). These surfactants of biological origin are largely produced by Pseudomonas spp. Pseudomonas aeruginosa produces two forms of rhamnolipids, mono- and di-rhamnolipids in liquid culture,. Rhamnolipids with one sugar molecule are defined as mono-rhamnolipids, while those with two sugar molecules are defined as dirhamnolipids. Some Pseudomonas species produce only mono-rhamnolipids, while others produce both. Jarvis and Johnson first reported rhamnolipid production by $P$. aeruginosa in 1949. They incubated $P$. aeruginosa in a nutrient medium containing $4 \%$ peptone and $3 \%$ glycerol in a shaking flask at $30{ }^{\circ} \mathrm{C}$ for four-five days and isolated $2.5 \mathrm{~g} / \mathrm{L}$ of the product. The first patent (US $4,628,030)$ for rhamnolipid production was received by Kaeppeli and Guerra-Santos (1986) for their study conducted with $P$. aeruginosa DSM 2659. Rhamnolipids are predominantly produced by $P$. aeruginosa, and the other Pseudomonas species that have been reported to produce rhamnolipids are $P$. chlororaphis (Gunther et al. 2005), P. putida (Wittgens et al. 2011; Nanganuru and Korropati 2012), P. fluorescens (Abouseoud et al. 2008; El-Amine Bendaha et al. 2012), $P$. nitroreducens (Onwosi and Odibo 2012), and $P$. alcaligenes (Oliveira 2009).Rhamnolipids reduce the surface tension of water from $72 \mathrm{mN} \cdot \mathrm{m}^{-1}$ to below $30 \mathrm{mN} \cdot \mathrm{m}^{-1}$ and the interfacial tension of the water/oil system from $43 \mathrm{mN} \cdot \mathrm{m}^{-1}$ to about 1 $\mathrm{mN} \cdot \mathrm{m}^{-1}$. In addition, they have many environmental applications, such as the enhancement of oil recovery, degradation of hydrocarbons, and removal of metals from soil (Bordoloi and Konwar 2008; Amani et al. 2010; Das and Chandran 2011).

In the last three decades, considerable research has been conducted on the production and application of rhamnolipids. This review aims to provide information on the industrial products used for rhamnolipid production by Pseudomonas spp. and the factors affecting this process.

\section{FACTORS AFFECTING PRODUCTION OF RHAMNOLIPIDS}

As with all biosurfactants, the composition and yield of rhamnolipid depends on the culture conditions as well as the producer strain. There are a number of studies in the literature about effects of various factors on rhamnolipid production, especially on yield. The carbon and nitrogen source, the amount of ions used in the medium and the culture conditions, such as $\mathrm{pH}$, temperature, and agitation, influence the quality and quantity of rhamnolipids.

\section{Carbon source}

Many microorganisms synthesize biosurfactants using different carbon sources. Studies indicate that the yield of a biosurfactant varies depending on the carbon source and the nutrient medium (Robert et al. 1989; Bodour et al. 2003; Soberon-Chavez et al. 2005). Crude oil, glucose, sucrose, and glycerol have been reported as good carbon sources for biosurfactant production (Guerra-Santos 1984; Desai and Banat 1997). Carbon sources used in biosurfactant production can be divided into three categories, including carbohydrates, hydrocarbons, and vegetable oils. Water-soluble carbon sources, 
such as glycerol, glucose, mannitol, and ethanol, have been recommended for rhamnolipid production by Pseudomonas spp. (Santa Anna et al. 2001; Silva et al. 2010).

\section{Nitrogen source}

Nitrogen is an essential component for microbial growth and enzyme production for fermentation processes and hence an important factor for biosurfactant production. Different nitrogen sources have been used for the production, such as peptone, urea, ammonium sulfate, ammonium nitrate, sodium nitrate, meat extract, and malt extract. Robert et al. (1989) observed that nitrate was the best nitrogen source for the biosurfactant production by Pseudomonas strain 44T1. Venkata Ramana and Karanth (1989) reported that nitrogen limitation caused increased biosurfactant production by $P$. aeruginosa. Guerra-Santos et al. (1986) determined that the maximum rhamnolipid yield was obtained after nitrogen limitation, at a C:N ratio of $16: 1$ to $18: 1$. Syldatk et al. (1985) showed that nitrogen limitation also changed the composition of the biosurfactant produced. Onwosi and Odibo (2012) reported a production level of $4.39 \mathrm{~g} / \mathrm{L}$ of rhamnolipids for $P$. nitroreducens with sodium nitrate as a nitrogen source, and the observed nitrogen source efficiency was in the order of sodium nitrate > yeast extract > urea. According to many studies, sodium nitrate was more effective than ammonium sulfate and urea for rhamnolipid production (Guerra-Santos et al. 1986; Santa-Anna et al. 2001; Jeong et al. 2004; Rashedi et al. 2005). Sodium nitrate has also been reported as the best nitrogen source for rhamnolipid production by $P$. aeruginosa (Wei et al. 2005; Prieto et al. 2008; Wu et al. 2008). According to Aboseoud et al. (2008), ammonium nitrate was the best nitrogen source for rhamnolipid production by P. fluorescens. Consequently, the results related with nitrogen sources vary depending on the Pseudomonas species used in the studies so nitrogen source should be selected according to the Pseudomonas species which will be used in the study. But generally it can be said that sodium nitrate and ammonium nitrate are best source for rhamnolipid production.

\section{Culture conditions}

pH: A wide variety of culture conditions have been tested for biosurfactant production to obtain large quantities of the product of interest. According to Guerra-Santos et al. (1984), the maximum rhamnolipid yield was obtained in the $\mathrm{pH}$ range from 6.0 to 6.5 , and the yield sharply decreased above $\mathrm{pH}$ 7.0. Mata-Sandoval et al. (2001) reported in their study with $P$. aeruginosa UG2 that neutral culture conditions ( $\mathrm{pH}$ 7.0) increased the average production levels of all rhamnolipid species by $25 \%$ compared to their production at slightly acidic conditions ( $\mathrm{pH}$ 6.25).

Temperature: The optimum temperature ranges have been identified to be $30-37{ }^{\circ} \mathrm{C}$ in a study by Wei et al. (2005) and $30-35{ }^{\circ} \mathrm{C}$ by Sahoo et al. (2011) with $P$. aeruginosa. Chen et al. (2007) reported the optimum temperature to be $37{ }^{\circ} \mathrm{C}$ based on their investigation of temperatures between 30 and $42^{\circ} \mathrm{C}$.

Agitation: The agitation speed and method applied during the incubation are important in the production of a biosurfactant to ensure oxygen transfer from the gas phase to the aqueous phase. Pimienta et al. (1997) reported that orbital shaking is more effective than lateral shaking. In studies with flasks, shaking speeds have been varied between 120 and $220 \mathrm{rpm}$. Wei et al. (2005) tested agitation speeds in the range between 50 and 250 $\mathrm{rpm}$ in their study with $P$. aeruginosa strains isolated from petrochemical waste waters and observed a better result at $200 \mathrm{rpm}$. As well as microorganisms, carbon and nitrogen sources, optimization of the culture medium and conditions is the significant parameter to increase rhamnolipid yield. Additionally, according to Banat et al. (2010), recombinant and mutant producer strains may give high yields of biosurfactants and can be an important step to their economical production.

\section{APPLICATIONS OF RHAMNOLIPIDS}

\section{Environmental applications of rhamnolipids}

Petroleum-based products are the major source of energy for industry and daily life. Oil spills into the environment are a main cause of water and soil pollution, and they can result in both immediate and long-term environmental damage. Biodegradation is a process including decomposition of organic material and removal of petroleum and other hydrocarbon pollutants from the environment by microorganisms, and it is cheaper than other remediation technologies (Das and Chandran 2011). Chemically synthesized surfactants have been used for enhanced oil recovery (EOR) and for oil spill clean-ups for decades. However, because of 
their toxicity and resistance to degradation, chemical surfactants can cause serious environmental problems (Mulligan 2005). Biosurfactants have been tested for EOR and were demonstrated to be effective in microbial enhanced oil recovery (MEOR), where their lower toxicity and biodegradability represent advantages. MEOR is a technique that can recover the residual oil using microorganisms or their products (Bordoloi and Konwar 2008; Amani et al. 2010). Rhamnolipids have been found to be effective compounds for MEOR, and they can change physical and chemical properties of crude oil and stimulate oil-water interactions that improve oil recovery (Amani et al. 2010, 2013; Amani 2015).

In Banat's (1995) and Reis et al. (2013) review discussing biosurfactant production and possible uses in MEOR and remediation of oil pollution, the following three main strategies were indicated, involving the use of biosurfactants in MEOR: (i) injection of biosurfactant-producing microorganisms into a reservoir through the well, with subsequent multiplication of the microorganisms in situ within the reservoir rocks; (ii) injection of selected nutrients into a reservoir to stimulate the growth of indigenous biosurfactantproducing microorganisms; and (iii) production of biosurfactants in bioreactors ex situ and their subsequent injection into a reservoir.

Various bacteria from the genus Pseudomonas, especially $P$. aeruginosa strains, are the best known bacteria capable of utilizing a number of aliphatic and aromatic hydrocarbons as carbon and energy sources. These bacteria can inhabit contaminated soils and enhance the availability and biodegradation of organic components (Das and Chandran 2011; Kadali et al. 2012; Saikia et al. 2012; Puskarova et al. 2013). Biosurfactants play a dual role in bioremediation by increasing the surface area and the bioavailability of hydrophobic, water-insoluble substrates.

There are a large number of research publications on rhamnolipid effectiveness in biodegradation as well as in cleanup of soils contaminated with gasoline and other hydrocarbons. Originally, Itoh and Suzuki showed in 1972 that hydrocarbon culture media stimulated the growth of a rhamnolipid-producing $P$. aeruginosa strain. Subsequent studies confirmed rhamnolipid effects on hydrocarbon biodegradation (Arino et al. 1998) and indicated that the addition of rhamnolipids enhanced biodegradation of hexadecane, octadecane, and $n$-paraffin in a liquid system and hydrocarbon mixtures in soil. The Exxon Valdez oil spill is a well-known example of biosurfactant use in bioremediation (Harvey 1990).

Zhang and Miller (1997) investigated rhamnolipid effects on octadecane dispersion and biodegradation and showed that octadecane mineralization increased from 5 to $20 \%$ within $84 \mathrm{~h}$ in the presence of $300 \mathrm{mg} / \mathrm{L}$ of rhamnolipids. Van Dyke et al. (1993) demonstrated a 25 to $70 \%$ increase in the recovery of hydrocarbons from a contaminated sandy loam soil and a 40 to $80 \%$ increase in the recovery of hydrocarbons from a silt loam soil upon use of $P$. aeruginosa rhamnolipids. Rahman et al. (2003) investigated the biodegradation of $n$-alkanes in petroleum sludge contaminated with $87.4 \%$ of oil and demonstrated that with the addition of rhamnolipids, C8-C11, C12-C21, C22-C31, and C32-C40 alkanes were degraded by $100 \%, 83-98 \%, 80-85 \%$, and $57-73 \%$, respectively, after 56 days. Several studies reported that rhamnolipids are efficient in the removal/cleanup of heavy metals due to interactions between their polar glycosidic groups and metal ions. Rhamnolipid interactions with organic compounds increase the bioavailability of the latter. Rhamnolipid surfactants have been shown to be effective in reducing oil concentrations in contaminated soils, and their addition at a low concentration $(80 \mathrm{mg} / \mathrm{L})$ to a diesel/water system increased biomass growth and diesel degradation (Whang et al. 2008).

Polycyclic aromatic hydrocarbons (PAHs) pollute the environment and are toxic, mutagenic, and carcinogenic compounds. They are emitted to the environment as byproducts of coal processing and by oil spills. The reason for prolonged presence of large-molecular-weight hydrophobic compounds in aquatic environments is their low solubility. Low aqueous solubility of PAHs limits their availability for microorganisms. This poses a potential problem for the bioremediation of an area contaminated with these compounds. Biosurfactants accelerate the utilization of hydrophobic compounds by increasing the solubility of PAHs for their bioremediation (Cameotra and Bollag 2003). Deschenes et al. (1996) reported that rhamnolipids are more effective than sodium dodecyl sulfate in increasing solubilization of PAHs. Daziel et al. (1996) demonstrated in their study that rhamnolipid production is responsible for an increase in the aqueous solubility of naphthalene. Zhang et al. (1997) investigated the effect of two forms of rhamnolipids on the dissolution and bioavailability 
of phenanthrene and found monorhamnolipid was more effective than dirhamnolipid for solubilization but phenanthrene within monorhamnolipid micelles was less bioavailable than phenanthrene within dirhamnolipid micelles. So they indicated that the effect of a surfactant on biodegradation is a combination of the solubilizing power of the surfactant and the bioavailability of the substrate within the surfactant micelles. an increase in both solubility and degradation. In another study, it was shown that adding a rhamnolipid producer, Pseudomonas spp. DS10129 , increased the bioremediation process in an oilcontaminated soil (Rahman et al. 2002). Similarly, Straube et al. (2003) reported that adding $P$. aeruginosa strain 64 enhanced the bioremediation in a soil contaminated with PAHs and pentachlorophenol. Kumar et al. (2008) reported that a crude biosurfactant from the Pseudomonas DHT2 strain isolated from an oil-contaminated soil enhanced the solubility of PAHs in a dosedependent manner.

Mulligan (2009) reviewed in detail environmental applications of biosurfactants for an enhanced clean-up of hydrocarbon- and metal-contaminated soils. Wen et al. (2009) have investigated the use of rhamnolipids for bioremediation of soils contaminated with $\mathrm{Cd}$ and $\mathrm{Zn}$ and reported that rhamnolipids remain in soil long enough to enhance the metal phytoextraction. In a study of Obayori et al. (2009), biodegradative properties of a biosurfactant produced by the Pseudomonas sp. LP1 strain were investigated for crude oil and diesel. The authors reported $92.34 \%$ degradation of crude oil and 95.29\% removal of diesel oil. Gonzini et al. (2010) observed that with the increasing dose of rhamnolipids, the gasoil removal efficiency increased up to $86.7 \%$. Zhang et al. (2011) investigated the effect of rhamnolipids on the remediation of a crude oil- and salt-contaminated soil. They observed a distinct decline in the total petroleum hydrocarbon (TPH) concentration in the soil when using rhamnolipids during a remediation period of 30 days, with a maximum TPH reduction of $86.97 \%$. Wana et al. (2011) investigated the selective adsorption of hexachlorobenzene (HCB) from a rhamnolipid solution by a powdered activated carbon (PAC) and observed that when a $25 \mathrm{~g} / \mathrm{L}$ rhamnolipid solution was applied the HCB leaching from soils was $55-71 \%$ after three cycles of cleaning and the HCB removal by the PAC was nearly 90\%. Pacwa-Plociniczak et al. (2014) investigated the Pseudomonas sp. P-1 strain isolated from a petroleum-contaminated soil for its bioremediation potential and indicated that the strain had the ability to degrade various hydrocarbons (hexadecane, crude oil, and fractions A5 and P3 of crude oil). In another study conducted by Gudina et al. (2015) with agro-industrial byproducts (corn steep liquor and molasses), rhamnolipids exhibited a better performance in removing oil from contaminated sand compared with two chemical surfactants (Enordet and Petrostep).

\section{Other applications}

Antimicrobial activity and anti-cellular effects of rhamnolipids produced by Pseudomonas spp. have been described by many authors in the literature. Rhamnolipids showed activity against a large variety of bacteria, including both Gram-negative (Salmonella typhimurium, Escherichia coli, and Enterobacter aerogenes) and Gram-positive bacteria (Staphylococcus aureus, Staphylococcus epidermidis, and Bacillus cereus) and fungi (Phytophthora infestans, Phytophthora capsici, Botrytis cinerea, Fusarium graminearum, Mucor spp., Cercospora kikuchii, Cladosporium cucumerinum, Colletotrichum orbiculare, Cylindrocarpon destructans, and Magnaporthe grisea) (Abolos et al. 2001; Rodrigues et al. 2006; Lotfabad et al. 2008; Onbasli and Aslim 2009; Sridhar et al. 2013). Yilmaz and Sidal (2005) reported that the antimicrobial activity against Gram-positive bacteria was better than that against Gram-negative bacteria. They explained this fact by the differences in the cell wall structure between Gram-positive and Gram-negative bacteria. It is known that Gram-negative bacteria have the membrane that is hardly permeable to hydrophobic and amphipathic molecules. In more recent years, it has been shown that rhamnolipids have antimicrobial activity against Listeria monocytogenes and show a synergistic effect when combined with nisin (a polycyclic antibacterial peptide) (Magalhaes and Nitschke 2013). Additionally, Araujoa et al. (2010) determined that a rhamnolipid inhibited L. monocytogenes adhesion and suggested that this surfactant could be explored as a potential agent to control L. monocytogenes. Interactions of the rhamnolipid produced by $P$. aeruginosa OBP1 with the cell surfaces of $S$. aureus MTCC 3160 and Klebsiella pneumoniae MTCC 618 were studied by Bharali et al. (2013), and rhamnolipid concentrations below the critical micelle concentration (CMC) ("CMC is defined as 
the concentration of surfactants above which micelles start to form.) exhibited no significant antibacterial activity. However, upon increasing the rhamnolipid concentration over the $\mathrm{CMC}$, a significant antibacterial activity was observed. Currently, rhamnolipids have been studied to determine their synergistic activities with antibiotics, essential oils, and various other agents (Ganesh et al. 2010; Das et al. 2014; Elouzi et al. 2014; Haba et al. 2014).

Thanomsub et al. (2007) investigated the chemical structures and biological activities of the rhamnolipids produced by $P$. aeruginosa B189 isolated from a milk factory waste. The culture produced two kinds of biosurfactants. Rhamnolipid A showed significant anti-proliferative activity against a human breast cancer cell line (MCF-7) with a minimum inhibitory concentration of 6.25 $\mu \mathrm{g} / \mathrm{mL}$, while rhamnolipid B showed activity against the insect cell line $\mathrm{C} 6 / 36$ at $50 \mu \mathrm{g} / \mathrm{mL}$. Also, rhamnolipids have been found to be effective for skin treatment, including wound healing with reduced fibrosis and wrinkle treatment (Piljac and Piljac 2007), thereby showing promise in pharmaceutical applications. Rhamnolipids are emulsifiers and surface-active detergents; therefore, detergent compositions, laundry products, shampoos, and soaps are also their usage areas (Parry et al. 2013).

\section{COST-EFFECTIVE SUBSTRATES FOR RHAMNOLIPID PRODUCTION}

Biosurfactant-producing companies have been discussed in detail in Sekhon Randhawa and Rahman's (2014) review. The authors indicated that there are still a very limited number of companies in the field that produce rhamnolipids at a marketable scale. There are six companies, including TeeGene Biotech Ltd. (UK), AGAE
Technologies LLC (USA), Jeneil Biosurfactant Co., LLC (USA), Paradigm Biomedical, Inc. (USA), Rhamnolipid Companies, Inc. (USA), and Henkel (Germany), involved in rhamnolipid production. In particular, rhamnolipids are used as cosmetic additives in Japan (Iwata Co., Japan, personal communication). In the same review, the authors mentioned that there are 42 patents and grants obtained on rhamnolipids. Despite their many advantages compared with synthetic surfactants, industrial production of biosurfactants has not been undertaken due to high investment costs. Although there have been studies focusing on low-cost production, the costs continue to remain high. Syldatk and Hausmann (2010) explained the reasons for a limited use of biosurfactants in industry, which include the use of expensive substrates, limited product concentrations, and the availability of only few pure compounds. As with all biosurfactants, there are three main strategies adopted in the world for the cost-effective rhamnolipid production: 1) utilization of rhamnolipid producer strains giving a high yield 2) using a non-expensive substrate and 3) development of a bioprocess including optimized culture conditions.

Using a low-cost material is a possible key to solve the cost problem; however, it is of great importance to select suitable products compatible with cell growth. Various cheap substrates are currently available as a carbon source in industrial biosurfactant production. In the future, waste substrates may become more important, since they are usually less expensive. Additionally, using waste substrates for biotechnological processes is beneficial for the environment.In the literature, there are many studies showing rhamnolipid production using various wastes. The wastes used for rhamnolipid production are shown in table 1 . 


\begin{tabular}{|c|c|c|c|}
\hline Source & RL (g/L) & References & Isolate \\
\hline $\begin{array}{l}\text { Olive oil mill effluent } \\
\text { (OOME) }\end{array}$ & 1.4 & $\begin{array}{l}\text { Mercade 1993;Sidal et al. } \\
2000\end{array}$ & Pseudomonas spp. \\
\hline Frying olive oil & $\begin{array}{l}2.7 \\
12.47\end{array}$ & $\begin{array}{l}\text { Haba et al. } 2000 \\
\text { Zhu et al. } 2007\end{array}$ & $\begin{array}{l}\text { Pseudomonas spp. } \\
\text { P. aeruginosa }\end{array}$ \\
\hline Frying coconut oil & 2.26 & George and Jayachandran & P. aeruginosa $D$ \\
\hline Frying soybean oil & 3.3 & $\begin{array}{l}2012 \\
\text { Lima et al.2009 }\end{array}$ & $P$. aeruginosaPACL \\
\hline $\begin{array}{l}\text { Soapstock, } \\
\text { Soybean soapstock }\end{array}$ & $\begin{array}{l}12 \\
11.7\end{array}$ & $\begin{array}{l}\text { Benincasa et al. } 2002 \\
\text { Nitschke et al. } 2005\end{array}$ & P. aeruginosa $L B I$ \\
\hline Molasses & $\begin{array}{l}0.24 \\
0.04 \\
1.45 \\
0.38 \\
\end{array}$ & $\begin{array}{l}\text { Patel and Desai } 1997 \\
\text { Rashedi et al.2005, } \\
\text { Raza et al.2007 } \\
\text { Onbasli and Aslim } 2009\end{array}$ & $\begin{array}{l}\text { P. aeruginosa GS3 } \\
\text { P. aeruginosa } \\
\text { Pseudomonas spp. }\end{array}$ \\
\hline Whey & & $\begin{array}{l}\text { Dubey and Juwarkar, } 2001 \\
\text { Praveesh et al., } 2011\end{array}$ & $\begin{array}{l}\text { P. aeruginosa BS2 } \\
\text { Pseudomonas spp. }\end{array}$ \\
\hline $\begin{array}{l}\text { Curd whey and distillery } \\
\text { waste }\end{array}$ & 2- 0.92 & $\begin{array}{l}\text { Babu et al.,1996, Dubey and } \\
\text { Juwarkar, } 2004\end{array}$ & $P$. aeruginosa $B S 2$ \\
\hline Sunflower oil wastes & 7.3 & $\begin{array}{l}\text { Benincasa and Accorsini, } \\
2008\end{array}$ & P. aeruginosa $L B I$ \\
\hline
\end{tabular}

\section{Agro-Industrial Wastes}

Agro-industrial wastes contain high amounts of carbohydrates and lipids and hence can be used as a rich carbon source for microbial growth. These wastes include plant oil extracts and wastes, distillery and whey wastes, olive oil mill effluents, cassava flour and its wastewater, and sugar cane and beet molasses. Among the agro-industrial waste products, molasses has been examined by many researchers. Molasses is a sweet, dark brown, concentrated syrup byproduct of the sugar cane and beet processing industries, which has a high sucrose concentration in the range of $50-55 \%$ by weight. Initially, Patel and Desai (1997) reported rhamnolipid production by $P$. aeruginosa GS3 using molasses and corn steep liquor as the carbon and nitrogen sources. Then, many other researchers followed the trend. Thus, Rashedi et al. (2005) investigated the possibility of using soy molasses as an inexpensive source for rhamnolipid production. They reported rhamnolipid production rates at molasses concentrations of $2,4,6,8$, and $10 \%$ to be $0.00065 \mathrm{~g} / \mathrm{L}, 4.556 \mathrm{~g} / \mathrm{L}, 8.94 \mathrm{~g} / \mathrm{L}, 8.85 \mathrm{~g} / \mathrm{L}$, and 9.09 $\mathrm{g} / \mathrm{L}$, with the rhamnolipid/biomass yield ratios of $0.003 \mathrm{~g}, 0.009 \mathrm{~g}, 0.053 \mathrm{~g}, 0.041 \mathrm{~g}$, and $0.213 \mathrm{~g}$, respectively. Raza et al. (2007) obtained the maximum rhamnolipid yield of $1.45 \mathrm{~g} / \mathrm{L}$ after $96 \mathrm{~h}$ of incubation of a $P$. aeruginosa EBN-8 mutant on $2 \%$ blackstrap molasses. Similarly, Onbasli and Aslim (2009) used molasses in their study conducted with $P$. luteola $\mathrm{B} 17$ and P. putida $\mathrm{B} 12$ and obtained the maximum rhamnolipid yield after a 12-h incubation with 5\% sugar beet molasses. Molasses distillery wastewater was investigated by $\mathrm{Li}$ et al. (2011), as an unconventional substrate for rhamnolipid production by $P$. aeruginosa GIM32, and $2.6 \mathrm{~g} / \mathrm{L}$ of rhamnolipids was obtained after a 64-h incubation. Gudina et al. (2015) obtained in their study the highest biosurfactant production yield of $3.2 \mathrm{~g} / \mathrm{L}$ using a culture medium containing corn steep liquor $(10 \%, \mathrm{v} / \mathrm{v})$ and molasses $(10 \%$, $\mathrm{w} / \mathrm{v})$.

The availability of agro-industrial wastes is usually locally confined and access difficulty to these wastes at large enough quantities is a handicap for large-scale production of biosurfactants. Additionally, agro-industrial wastes have variable components so the actual concern is sustainability of same wastes with same ingridients for production.

\section{Dairy and distillery industry by-products}

Large quantities of whey, including curd whey, whey waste, and cheese whey, are easily available as a substrate for microbial production of surfactants (Dubey and Juwarkar 2001, 2004; Praveesh et al. 2011; Dubey et al. 2012). Whey is the most important byproduct of the dairy industry, and the liquid contains up to $75 \%$ of lactose and $15 \%$ of protein in dry matter, as well as vitamins 
and minerals. Whey waters constitute the major part of the total pollution load in the dairy industry, and whey disposal is still an important environmental problem. Production of rhamnolipids by $P$. aeruginosa using whey as a carbon source has been investigated by Dubey and Juwarkar (2001), and a $1 \mathrm{~g} / \mathrm{L}$ rhamnolipid yield could be achieved. In recent years, Colak and Kahraman (2013) have conducted a study using cheese whey and olive oil mill wastewater and obtained the highest rhamnolipid yield from whey in cultures grown at $37{ }^{\circ} \mathrm{C}$ and $100 \mathrm{rpm}$, reaching 9.6 and $13.3 \mathrm{~g} / \mathrm{L}$ within $72 \mathrm{~h}$ for a $P$. aeruginosa strain and its recombinant derivative, respectively.

\section{Oil and oil processing wastes}

Several vegetable oils and wastes from the oil processing industry have been used for the production of microbial surface-active compounds. The oils used for rhamnolipid production are listed in table 2 .

\begin{tabular}{|c|c|c|c|}
\hline Source & RL $(g / L)$ & References & Isolate \\
\hline Olive oil & $\begin{array}{l}0.8 \\
0.12 \\
0.19\end{array}$ & $\begin{array}{l}\text { Robert et al., } 1989 \\
\text { Abouseoud et al., } 2008 \\
\text { El- Amine Bendaha et al.,2012 } \\
\text { Moussa et al., } 2014\end{array}$ & $\begin{array}{l}\text { P. aeruginosa } 44 \mathrm{~T} 1 \\
\text { P. fluorescens } \\
\text { P.aeruginosa P.B: } 2 \\
\text { P.fluorescens P.V:10 } \\
\text { P. aeruginosa TMN }\end{array}$ \\
\hline Sunflower oil & $\begin{array}{l}4.9 \\
39 \\
3 \\
0.187\end{array}$ & $\begin{array}{l}\text { Benincasa et al., } 2002 \\
\text { Müller et al., } 2010 \\
\text { Rikalovic et al., } 2012 \\
\text { Xia et al., 2012 } \\
\text { Peter and Singh, } 2014\end{array}$ & $\begin{array}{l}\text { P. aeruginosa } \mathrm{LB} 1 \\
P . \text { aeruginosa } \mathrm{PAO} 1 \\
P . \text { aeruginosa } \mathrm{san}-\mathrm{ai} \\
P . \text { aeruginosa } W J-I \\
\text { P.fluorescens }\end{array}$ \\
\hline Safflower oil & 2.98 & Rahman et al., 2002 & P.aeruginosa DS10-129 \\
\hline Soybean oil & $\begin{array}{l}4.31 \\
1.42 \\
0.437\end{array}$ & $\begin{array}{l}\text { Rahman et al.,2002 } \\
\text { Prieto et al., } 2008 \\
\text { Abdel-Mawgoud et al., } 2009 \\
\text { Peter and Singh, } 2014\end{array}$ & $\begin{array}{l}\text { P.aeruginosa DS10-129 } \\
\text { P. aeruginosa LBM } 10 \\
\text { P. aeruginosa Bs } 20 \\
\text { P.fluorescens }\end{array}$ \\
\hline Rapeseed oil & 45 & Trummler et al., 2003 & P. aeruginosa DSM 2874 \\
\hline Fish oil & 17 & Lee et al., 2004 & $\begin{array}{l}P . \quad \text { aeruginosa BYK- } \\
\text { 2KCTC }\end{array}$ \\
\hline Palm oil & $\begin{array}{l}2.91 \\
0.289\end{array}$ & $\begin{array}{l}\text { Thaniyavarn et al., } 2006 \\
\text { Peter and Singh, } 2014\end{array}$ & $\begin{array}{l}P . \text { aeruginosa } \mathrm{A} 41 \\
P . \text { fluorescens }\end{array}$ \\
\hline Canola oil & $17-24$ & Sim et al., 1997 & P.aeruginosa $\mathrm{UW}-1$ \\
\hline Babassu oil & 0.2 & Santa Anna et al., 2001 & P.aeruginosa PA1 \\
\hline $\begin{array}{l}\text { Brazilian nut oil, } \\
\text { passion fruit oil }\end{array}$ & $\begin{array}{l}9.9 \\
9.2\end{array}$ & Costa et al., 2006 & P. aeruginosa $L B I$ \\
\hline
\end{tabular}

Vegetable oils, such as soybean oil, corn oil, canola oil, and olive oil are major sources for the highest production of rhamnolipids. First, Mercade et al. (1993) used a vegetable oil from the distillation process and found it to be effective for rhamnolipid production by Pseudomonas strains. Thaniyavarn et al. (2006) investigated different oils as carbon sources for rhamnolipid production by $P$. aeruginosa A41 isolated from seawater in the Gulf of Thailand and determined the yields of the biosurfactant to be $6.58,2.91$, and $2.93 \mathrm{~g} / \mathrm{L}$ with olive oil, palm oil, and coconut oil, respectively. Although they obtained the highest yield with olive oil, the authors indicated that the biosurfactant obtained from palm oil performed best in lowering the surface tension of the medium. In the study of 
El-Amine Bendaha et al. (2012), P. fluorescens P.V:10 and P. aeruginosa P.B:2 isolated from a soil contaminated with hydrocarbons (kerosene, kerosene and diesel, and olive oil) were investigated for rhamnolipid production. Nutrient broth supplemented with olive oil was determined to be the best medium for rhamnolipid production. As much as carbon sources used for production, method optimization is the important point for obtaining the best yield. Ji et al (2016) indicated that maximum production of the RLs was obtained after optimization of the culture conditions, with a 6.85-fold increase in the yield of the RLs, up to 12.6 $\mathrm{g} / \mathrm{L}$ with olive oil, relative to the yield before optimization.

The other carbon source for rhamnolipid production is sunflower oil. Benincasa et al. (2002) obtained $4.9 \mathrm{~g} / \mathrm{L}$ and $12 \mathrm{~g} / \mathrm{L}$ rhamnolipid from $P$. aeruginosa LBI strain using sunflower oil and sunflower oil soapstock, respectively with shaking flask method but they indicated that rhamnolipid concentration with soapstock achived $15.9 \mathrm{~g} / \mathrm{L}$ when biorector was used for production. It is known that more rhamnolipid amounts are obtained with batch bioreactor cultivation process in production. Similarly Müller et al.(2010) in their study conducted with P.aeruginosa PAO1 used sunflower oil as a carbon source and batch bioreactor cultivation method and they obtained 39 $\mathrm{g} / \mathrm{L}$ rhamnolipid after $90 \mathrm{~h}$ cultivation. Trummler et al. (2003) achieved best results and product yields up to $45 \mathrm{~g} / \mathrm{L}$ with rapeseed oil using fed batch process.

There are limited numbers of studies in the literature on other Pseudomonas species, except $P$. aeruginosa using oils. Rhamnolipid production by $P$. alcaligenes using palm oil was reported by Oliveira et al. (2009). Peter and Singh (2014) obtained the highest rhamnolipid yield for $P$. fluorescens with soybean oil $(0.437 \mathrm{~g} / \mathrm{L})$, followed by coconut oil $(0.299 \mathrm{~g} / \mathrm{L})$, palm oil $(0.289 \mathrm{~g} / \mathrm{L})$, mustard oil $(0.233 \mathrm{~g} / \mathrm{L})$, sunflower oil $(0.187 \mathrm{~g} / \mathrm{L})$, and olive oil $(0.108 \mathrm{~g} / \mathrm{L})$.

Additionally to the oils, oil process wastes are alternative for rhamnolipid production. Nitschke et al. (2010) used soybean oil soapstock as an alternative source for production of rhamnolipid by
$P$. aeruginosa LBI strain. The rhamnolipids obtained in the study were characterized in terms of their chemical structure. The authors concluded that soybean oil soapstock could be used as an alternative low-cost substrate for rhamnolipid production. In addition to vegetable oils and oil process wastes, some studies investigated effects of waste frying oils on rhamnolipid production. Haba et al. (2000) used waste frying sunflower and olive cooking oils for rhamnolipid production by $P$. aeruginosa 47T2 and obtained $2.7 \mathrm{~g} / \mathrm{L}$ of rhamnolipids. Rhamnolipid production by $P$. aeruginosa ATCC 9027 with waste frying oil as a sole carbon source was studied by Luo et al. (2013) using the response surface method. The maximum rhamnolipid production was $8.5 \mathrm{~g} / \mathrm{L}$ within $72 \mathrm{~h}$. Benincasa and Accorsini (2008) obtained $7.5 \mathrm{~g} / \mathrm{L}$ of rhamnolipids from $P$. aeruginosa LBI using a fermentation medium composed of acidic wastewater and soapstock from a sunflower-oil process. Colak and Kahraman (2013) examined rhamnolipid production using olive oil mill wastewater and whey in their study conducted with a $P$. aeruginosa strain and its recombinant derivative containing the Vitreoscilla hemoglobin gene. They obtained higher rhamnolipid yields with whey, which reached 9.6 and $13.3 \mathrm{~g} / \mathrm{L}$ after a $72-\mathrm{h}$ incubation of the wild-type and recombinant strains, respectively.

Mixture of carbon sources have been used in some studies in the literature for increasing rhamnolipid production. Thus, Camilios Neto et al. (2011) investigated rhamnolipid production using a solidstate cultivation method with different carbon sources and obtained the best rhamnolipid production, $45 \mathrm{~g} / \mathrm{L}$ of the impregnating solution used, with a $50: 50(\mathrm{~m} / \mathrm{m})$ mixture of sugarcane bagasse and corn bran, supplemented with a solution containing $6 \%(\mathrm{v} / \mathrm{v})$ each of glycerol and soybean oil.

\section{Other substrates for rhamnolipid production}

In addition to the products described above, other substrates were also used for rhamnolipid production in some studies. These sources are listed in Table 3. 


\begin{tabular}{|c|c|c|c|}
\hline Source & RL (g/L) & References & Isolate \\
\hline Kefir & 11.7 & $\begin{array}{l}\text { Kaskatepe et al., } \\
2015 \mathrm{a}\end{array}$ & P. aeruginosa ATCC 9027 \\
\hline Fish meal & 12.3 & $\begin{array}{l}\text { Kaskatepe et al., } \\
\text { 2015a }\end{array}$ & P. aeruginosa ATCC 9027 \\
\hline $\begin{array}{l}\text { Pulps of sunflower, } \\
\text { hazelnut and barley }\end{array}$ & $\begin{array}{l}6.7-8.5- \\
9.2\end{array}$ & $\begin{array}{l}\text { Kaskatepe et al., } \\
2015 b\end{array}$ & P.putida and P.pachastrella \\
\hline $\begin{array}{l}\text { n-hexadecane, Paraffin } \\
\text { oil }\end{array}$ & $0.13-0.26$ & $\begin{array}{l}\text { Santa Anna et al., } \\
2001\end{array}$ & P.aeruginosa PA1 \\
\hline Glycerol & 0.69 & $\begin{array}{l}\text { Santa Anna et al., } \\
2001\end{array}$ & P.aeruginosa PA1 \\
\hline Orange fruit peelings & 9.18 & $\begin{array}{l}\text { George and } \\
\text { Jayachandran, } 2009\end{array}$ & P. aeruginosa МТCC 2297 \\
\hline
\end{tabular}

Santa Anna et al. (2001) investigated the rhamnolipid production by $P$. aeruginosa PA1 using different carbon sources, including $n$ hexadecane, paraffin oil, glycerol, and babassu oil, and indicated that the best results were obtained with glycerol. Glycerol can be obtained from renewable substrates, including hydrolysis of triglycerides from animal fats and vegetable oils of different purities, and can also be produced by petrochemical processes. Crude glycerol was used in studies, but unfortunately for trading utilization its prices are relatively high (Kosaric and Sukan 2015). Priya and Usharani (2009) investigated the effects of vegetable oil, kerosene, petrol, and diesel on biosurfactant production by $P$. aeruginosa and indicated that diesel was the best carbon source for the production. George and Jayachandran (2009) used various costeffective waste materials, such as orange and lime peelings, carrot peel waste, coconut oil cake, and banana waste for rhamnolipid production by $P$. aeruginosa MTCC 2297 and found that the orange peel was the best substrate generating $9.18 \mathrm{~g} / \mathrm{L}$ of rhamnolipid biosurfactants.

In our previous study (Kaskatepe et al. 2015a), rhamnolipid production by $P$. aeruginosa ATCC 9027 was investigated using fish meal, which is a fish oil factory waste with high protein and mineral contents, and kefir, which is a fermented milk drink containing lactose, casein, albumin, fat, and good amounts of elements such as calcium, magnesium, phosphorus, fluorine, and selenium. As a result, 11.7 and $12.3 \mathrm{~g} / \mathrm{L}$ of rhamnolipids were obtained from kefir and fish meal, respectively, after sevenday incubation at $35{ }^{\circ} \mathrm{C}$ and $150 \mathrm{rpm}$. In literature survey, we found no study using fish meal, but found two using fish oil. Lee et al. (2004), while studying $P$. aeruginosa BYK-2 KCTC 18012P strain, used fish oil (25 g/L) as carbon source and obtained17 g/L rhamnolipid. On the other hand, Prieto et al. (2008) used soybean- and fish oil in their study. They added $40 \mathrm{~g} / \mathrm{L}$ from each oils in the basal medium and reported $0.94 \mathrm{~g} / \mathrm{L}$ rhamnolipid production in soybean oil but noted less amount of rhamnolipid in fish oil. Fish meal, for being produced from unprocessed fish waste and low cost, can be a more suitable source for rhamnolipid production. In another study, we tried to increase the rhamnolipid production by $P$. putida and $P$. pachastrellae strains by formulating different media using pulps of barley, hazelnut, and sunflower. The best media for rhamnolipid production were determined to be the barley pulp $(9.2 \mathrm{~g} / \mathrm{L})$ for $P$. pachastrellae and the hazelnut $(8.5$ $\mathrm{g} / \mathrm{L})$ and sunflower $(6.7 \mathrm{~g} / \mathrm{L})$ pulps for $P$. putida (Kaskatepe et al. 2015b).

\section{FUTURE PERSPECTIVES OF RHAMNOLIPID}

As it seen in the studies, the main aim is increase the rhamnolipid production with low-cost, for this purpose, different raw material, wastes, production methods and culture conditions are used in studies and the results are vary according to these variable factors. Despite the all studies and promising features of rhamnolipids, the economics of their production is a major problem for commercialization. There is still no economically technology for purifying rhamnolipids at industrial scale and also accessing cheap substrate is a barrier for low-cost production. Kosaric and Sukan (2015) have drawn attention to important issues. The 
authors indicated that the local availability of substrates plays an important role in the calculations of the production price because some resources are only generated at very few production sites.

Furthermore, some resources may not be present in large enough quantities to sustain large-scale production. According to the authors, the second major factor is substance purity. When using industrial wastes or other non-pure substrates, such as a feedstock, the main medium composition needs to be investigated. It is possible to define a typical composition; however, it varies among different batches. Thus, the process requires advanced control for standardization.

Some of the important criteria that need to be considered for production on industrial scale are as follows; the need for cost effective raw material and supply raw material with same composition, potential microorganisms with enhanced production capacity, economical production technologies and purification methods. Interdisciplinary research approaches in combination with the technologies of large-scale fermentation and genetic engineering by taking into consideration these parameters are significant to claim rhamnolipid as the commercial product of future.

\section{CONCLUSIONS}

Rhamnolipids have a big potential, especially in environmental applications for the remediation of contaminated soils due to their biodegradability and low toxicity and in medical fields due to their antimicrobial activities. Rhamnolipids are an alternative to synthetic surfactants, but their industrial use is still limited because of high costs. Low-cost production and discovery of novel rhamnolipid-producing strains characterized by better yields are the most important keys for rhamnolipids to have a corner on the global market of surfactants. Multidisciplinary research needs to be focused on discovery of novel strains or obtain new strains with genetic engineering, accessing cheap substrates and economical production technology. More studies should be carried out to improve low cost effective production media and process.

\section{REFERENCES}

1. Abdel-Mawgoud A, Aboulwafa M, Hassouna N. Characterization of rhamnolipid produced by Pseudomonas aeruginosa isolate Bs20, Appl Biochem Biotechnol, 2009;15: 329-345.

2. Abouseoud M, Maachi R, Amrane A, Biosurfactant Production from olive oil by Pseudomonas fluorescens, Communicating Current Research and Educational Topics and Trends in Applied Microbiology 2007; 340-347.

3. Abouseoud M, Maachi R, Amrane A, Boudergua S, Nabi A. Evaluation of different carbon and nitrogen sources in production of biosurfactant by Pseudomonas fluorescens. Desalination 2008; 223:143-151.

4. Amani H. Study of enhanced oil recovery by rhamnolipids in a homogeneous $2 \mathrm{D}$ micromodel. $J$ Petrol Sci Eng., 2015;128: 212-219.

5. Amani H, Muler MM, Syldatk, C, Hausmann R. Production of microbial rhamnolipid by Pseudomonas aeruginosa MM1011 for ex situ enhanced oil recovery. Appl Biochem Biotechnol, 2013;170:1080-1093.

6. Amani, H., Sarrafzadeh, M.H., Haghighi, M., Mehrnia, M.R., Comparative study of biosurfactant producing bacteria in MEOR applications., Journal of Petroleum Science and Engineering, 2010, vol.75, pp.209-214.

7. Anandara B, Thivakaran P, Isolation And Production of Biosurfactant Producing Organism From Oil Spilled Soil. Biosci Tech, 2010;1(3): 120126.

8. Araujoa LV, Abreub F, Linsb U, Santa Anna LMM, Nitschkec M, Freire DMG. Rhamnolipid and surfactin inhibit Listeria monocytogenes adhesion. Food Research International, 2010;.44(1): 481488.

9. Arino S, Marchal R, Vandecasteele JP. Involvement of a rhamnolipid-producing strain of Pseudomonas aeruginosa in the degradation of polycyclic aromatic hydrocarbons by a bacterial community. $J$ Appl Microbiol, 1998;84:769-776.

10. Babu PS, Vaidya AN, Bal AS, Kapur R, Juwarkar A, Khanna P. Kinetics of biosurfactant production by Pseudomonas aeruginosa strain BS2 from industrial wastes. Biotechnol. Lett, 1996;18:263268.

11. Banat IM. Biosurfactants production and possible uses in microbial enhanced oil recovery and oil pollution remediation-a review. Bioresour. Technol, 1995; 51:1-12.

12. Banat IM, Franzetti A, Gandolfi I, Bestetti G, Martinotti MG, Fracchia L, Smyth TJ, Marchant R., Microbial biosurfactants production, applications and future potential, Appl Microbiol Biotechnol, 2010: 87:.427-444.

13. Benincasa M, Accorsini FR. Pseudomonas aeruginosa $L B I$ production as an integrated process 
using the wastes from sunflower-oil refining as a substrate. Bioresour Technol, 2008; 99:3843-9.

14. Benincasa M, Contiero J, Manresa MA, Moraes IO. Rhamnolipid production by Pseudomonas aeruginosa LBI growing on soapstock as the sole carbon source. J. FoodEng, 2002; 54:283-288.

15. Benincasa M, Abolos A, Oliveira I, Manresa A. Chemical structure, surface properties and biological activities of the biosurfactant produced by Pseudomonas aeruginosa LBI from soapstock. Anton. Leeuw. Int. J.G, 2004;85:1-8.

16. Bharali P, Saikia JP, Raya A, Konwarc BK. Rhamnolipid (RL) from Pseudomonas aeruginosa OBP1: A novel chemotaxis and antibacterial agent, Colloids and Surfaces B: Biointerfaces, 2013; 103:502-509.

17. Bodour AA, Drees KP, Maier RM. Distribution of biosurfactant-producing bacteria in undisturbed and contaminated arid southwestern soils, Appl. Environ. Microbiol, 2003; 69(6): 3280-3287.

18. Bordoloi NK, Konwar BK. Microbial surfactantenhanced mineral oil recovery under laboratory conditions, Colloids and Surfaces B: Biointerfaces, 2008; 63(1):73-82.

19. Cameotra SS, Bollag JM, Biosurfactant-Enhanced Bioremediation of Polycyclic Aromatic Hydrocarbons, Crit. Rev. Env. Sci. Technol, 2003; 33;111-126.

20. Camilios-Neto D, Bugay C, Santana-Filho AP, Joslin T, De Souza LM, Sassaki GL, et al. Production of rhamnolipids in solid-state cultivation using a mixture of sugarcane bagasse and corn bran supplemented with glycerol and soybean oil, Appl Microbiol Biotechnol, 2011; 89: 395-1403.

21. Chen S, Wei Y, Chang J, Repeated pH-stat fedbatch fermentation for rhamnolipid production with indigenous Pseudomonas aeruginosa S2, Appl. Microbiol. Biotechnol 2007; 76(1):67-74.

22. Colak AK, Kahraman H. The use of raw cheese whey and olive oil mill wastewater for rhamnolipid production by recombinant Pseudomonas aeruginosa. Environmental and Experimental Biology. 2013;11: 125-130.

23. Cooper DG, Goldenberg BG. Surface-active agents from two Bacillus species, Appl. Environ. Microbiol, 1987; 53(2): 224-229.

24. Costa SG, Nitschke M, Haddad R, Eberlin MN, Contiero J. Production of Pseudomonas aeruginosa LBI rhamnolipids following growth on Brazilian native oils. Pro Biochem, 2006; 41: 483-488.

25. Das N, Chandran $\mathrm{P}$, Microbiol degradation of petroleum hydrocarbon contaminants: an overview. Biotechnol Res Int., 2011, doi:10.4061/2011/941810

26. Das P, Yang XP, Ma LZ. Analysis of biosurfactants from industrially viable Pseudomonas strain isolated from crude oil suggests how rhamnolipids congeners affect emulsification property and antimicrobial activity, Front Microbiol, 2014; 5:696.

27. Daziel E, Paquette G, Vellemur R, Lepins F, Bisaillnon JG. Biosurfactant production by a soil Pseudomonas strain growing on PAH's, Appl Environ Microbiol, 1996; 62: 1908-1912.

28. Desai JD, Banat IM. Microbial production of surfactants and their commercial potential. Microbiology and Molecular Biology Reviews, 1997; 61:47-64.

29. Deschenes L, Lafrane P, Villeneuve JP, Samson R. Adding sodium dodecyl sulphate and Pseudomonas aeruginosa $U G 2$ biosurfactants inhibits polyocylic hydrocarbon biodegradation in a weathered creosote contaminated soil, Appl. Micbiol. Biotechnol, 1996; 46:638-646.

30. Dubey, K., Charde PN, Meshram SU, Yadav SK, Singh S, Juwarkar AA. Potential of new microbial isolates for biosurfactant production using combinations of distillery waste with other industrial wastes, J Petrol Environ Biotechnol, 2012; doi:10.4172/2157-7463.S1-002

31. Dubey K, Juwarkar A, Distillery and curd whey wastes as viable alternative sources for biosurfactant production. World J.Microbiol.Biotechnol. 2001; 17: 61-69.

32. Dubey K, Juwarkar A. Determination of genetic basis for biosurfactant production by Pseudomonas aeruginosa strain BS2, Indian J.Biotechnol. 2004; 3:74-81.

33. El-Amine Bendaha M, Mebrek S, Naimi M, Tifrit, A, Belaouni HA et al., Isolation and Comparison of Rhamnolipids Production in Pseudomonas aeruginosa P.B:2 and Pseudomonas fluorescens P.V:10, Open Access Scientific Reports. 2012;1: 544.

34. Elouzi AA, Gusbi AM, Elgerbi AM. Efficacy Enhancement of Hydrophobic Antibiotics Employing Rhamnolipid as Biosurfactant, J Am Sci, 2014; 10(1):93-98.

35. Ganesh KC, Mamidyala SK, Das B, Sridhar B, Devi GS, Karuna MS. Synthesis of Biosurfactant-Based Silver Nanoparticles with Purified Rhamnolipids Isolated from Pseudomonas aeruginosa BS-161R, J. Microbiol. Biotechnol, 2010; 20(7): 1061-1068.

36. George S, Jayachandran K. Analysis of rhamnolipid biosurfactants produced through submerged fermentation using orange fruit peelings as sole carbon source,Appl Biochem Biotechnol.2009;158:694-705.

37. George S, Jayachandran K. Production and characterization of rhamnolipid biosurfactant from waste frying coconut oil using a novel Pseudomonas aeruginosa D. J Appl Microbiol. 2012; 114: 373383.

38. Gonzini O, Plaza A, Di Palma L, Lobo MC. Electrokinetic remediation of gasoil contaminated 
soil enhanced by rhamnolipid, J Appl Electrochem, 2010;40:1239-1248.

39. Gudiña EJ, Rodrigues AI, Alves E, Domingues MR, Teixeira JA. Rodrigues, L.R., Bioconversion of agro-industrial by-products in rhamnolipids toward applications in enhanced oil recovery and bioremediation, Bioresour Technol, 2015; 177:8793.

40. Guerra-Santos LH, Kappeli OR, Fiechter A. Pseudomonas aeruginosa biosurfactant production in continuous culture with glucose as carbon source, Appl. Environ. Microbiol, 1984; 48 (2): 301-305.

41. Guerra-Santos LH, Kappeli OR, Fiechter A. Dependence of Pseudomonas aeruginosa continous culture biosurfactant production on nutritional and environmental factors, Appl. Microbiol. Biotechnol, 1986; 24(6): 443-448.

42. Gunther NW, Nuñez A, Fett W, Solaiman DKY. Production of rhamnolipids by Pseudomonas chlororaphis, a nonpathogenic bacterium, Appl Environ Microbiol, 2005; 71(5): 2288-2293.

43. Haba E, Bouhdid S, Torrego-Solana N, Marqués AM, Espuny MJ, García-Celma MJ. et al. Rhamnolipids as emulsifying agents for essential oil formulations: antimicrobial effect against Candida albicans and methicillin-resistant Staphylococcus aureus, Int J Pharm, 2014;.476(1-2): 134-41.

44. Haba E, Espuny MJ, Busquets M, Manresa A., Screening and production of rhamnolipids by Pseudomonas aeruginosa 47T2 NCIB 40044 from waste frying oils, J Appl Microbiol, 2000; 88: 379 387.

45. Harvey S, Elashvill I, Valdes JJ, Kamely D, Chakrabarty AM, Enhanced removal of Exxon Valdez spilled oil from Alaskan gravel by a microbial surfactant, Biotechnology, 1990; 8:.228230.

46. Itoh S, Suzuki T. Effect of rhamnolipids on growth of Pseudomonas aeruginosa mutant deficient in nparaffin-utilizing ability, Agric Biol Chem, 1972;36: 2233-2235.

47. Jarvis FG, Johnson MJ. A glyco-lipid produced by Pseudomonas aeruginosa, J. Am. Chem. Soc, 1949; 71:. 4124-4126.

48. Jeong HS, Lim DJ, Hwang SH, Ha SD, Kong JY. Rhamnolipid production by Pseudomonas aeruginosa immobilised in polyvinyl alcohol beads, Biotechnol Lett, 2004; 26(1):35-9.

49. Ji F, Li L, Ma S, Wang J, Bao Y. Production of rhamnolipids with a high specificity by Pseudomonas aeruginosa M408 isolated from petroleum-contaminated soil using olive oil as sole carbon source. Ann Microbiol,2016, doi 10.1007/s13213-016-1203-9.

50. Kadali KK, Simons KL, Skuza PP, Moore RB, Ball AS. A complementary approach to identifying and assessing the remediation potential of hydrocarbonoclastic bacteria. J Microbiol Meth. 2012;88:348-355.

51. Kaeppeli O, Guerra- Santos L. Process for the production of rhamnolipids. 1986, Patent no US $4628030 \mathrm{~A}$.

52. Kaskatepe B, Yildiz S, Gumustas, M, Ozkan SA. Biosurfactant production by Pseudomonas aeruginosa in kefir and fish meal. Braz. J. Microbiol. 2015; 46(3):855-859.

53. Kaskatepe B, Yildiz S, Gumustas, M, Ozkan SA. Rhamnolipid production by Pseudomonas putida IBS036 and Pseudomonas pachastrellae LOS20 with using pulps. Curr Pharm Anal. 2015, (Accepted).

54. Kosaric N, Sukan FV. Biosurfactants, Production and Utilization-Processes, Technologies and Economics. CRC Press, 2015;86-88.

55. Kumar M, León V, De Sisto Materano A, Ilzins OA, Luis L. Biosurfactant production and hydrocarbondegradation by halotolerant and thermotolerant Pseudomonas sp. World J Microbiol Biotechnol, 2008; 24(7):1047-1057.

56. Lee KM, Hwang, SH, Ha SD, Jang JH, Lim DJ, Kong JY. Rhamnolipid production in batch and fedbatch fermentation using Pseudomonas aeruginosa BYK-2 KCTC 18012P. Biotechnol Bioproc E. 2004; 9(4):267-273.

57. Li AH, Xu MY, Sun W, Sun GP. Rhamnolipid Production by Pseudomonas aeruginosa GIM 32 Using Different Substrates Including Molasses Distillery Wastewater.Appl Biochem Biotechnol, 2011;163:600-611.

58. Lima CJ, Ribeiro EJ, Sérvulo EF, Resende MM, Cardoso VL. Biosurfactant production by Pseudomonas aeruginosa grown in residual soybean oil. Appl Biochem Biotechnol. 2009;152(1):156-68.

59. Lotfabad T, Shahcheraghi F, Shooraj F. Assessment of antibacterial capability of rhamnolipids produced by two indigenous Pseudomonas aeruginosa strains. Jundishapur J Microbiol. 2008; 6(1): 29-35.

60. Luo Z, Yuan XZ, Zhong H, Zeng GM, Liu ZF, Ma $\mathrm{XL}$, Zhu Y. Optimizing rhamnolipid production by Pseudomonas aeruginosa ATCC 9027 grown on waste frying oil using response surface method and batch-fed fermentation. Journal of Central South University, 2013; 20 (4):1015-1021.

61. Magalhaes L, Nitschke M. Antimicrobial activity of rhamnolipids against Listeria monocytogenes and their synergistic interaction with nisin, Food Control. 2013; 29(1): 138-142.

62. Mata-Sandoval JC, Karns J, Torrents A. Effect of nutritional and environmental conditions on the production and composition of rhamnolipids by $P$. aeruginosa UG2, Microbiol. Res, 2001; 55: 249256.

63. Mercade ME, Manresa MA, Robert M, Espuny MJ, Andrés, C. Guinea J. Olive oil mill effluent 
(OOME): new substrate for biosurfactant production, Bioresour.Technol, 1993; 43:1-6.

64. Moussa TAA, Mohamed MS, Samak N. Production and characterization of di-rhamnolipid produced by Pseudomonas aeruginosa TMN. Braz J Chem Eng, 2014; 31(04):867 - 880.

65. Müller MM, Hörmann B, Syldatk C, Hausmann R. Pseudomonas aeruginosa PAO1 as a model for rhamnolipid production in bioreactor systems, Appl Microbiol Biotechnol. 2010;87(1):167-74.

66. Mulligan $\mathrm{CN}$, Environmental applications for biosurfactants, Environ Pollut, 2005;133(2):183-98.

67. Mulligan CN. Recent advanced in the environmental applications of biosurfactants, Curr Opin Colloid Interface Sci, 2009;14: 372-378.

68. Nanganuru HY, Korrapati N. Studies on the production of rhamnolipids by Pseudomonas putida. International Journal of Research in Computer Science, 2012. 2(4); 19-21.

69. Nitschke M, Costa SG, Haddad R, Goncalves LA, Eberlin MN, Contiero J. Oil wastes as unconventional substrates for rhamnolipid production by Pseudomonas aeruginosa LBI, Biotechnol Prog, 2005;21:1562-1566.

70. Nitschke M, Costa SGVAO, Contiero J. Structure and applications of a rhamnolipid surfactant produced in soybean oil waste, Appl Biochem Biotechnol, 2010;160:2066-2074.

71. Obayori OS, Ilori MO, Adebusoye SA, Oyetibo GO, Omotayo AE, Amund OO. Degradation of hydrocarbons and biosurfactant production by Pseudomonas sp. strain LP1. World J. Microbiol. Biotechnol, 2009; 25:1615-1623.

72. Oliveira FJS, Vazquez L, Campos NP, França FP. Production of rhamnolipids by a Pseudomonas alcaligenes strain. Process Biochemistry, 2009;44(4): 383-389.

73. Onbasli D, Aslim B. Bio surfactant production in sugar beet molasses by some Pseudomonas spp. J. Environ.Biol. 2009; 30:161-163.

74. Onwosi CO, Odibo FJC, Effects of carbon and nitrogen sources on rhamnolipid biosurfactant production by Pseudomonas nitroreducens isolated from soil, World J Microbiol Biotechnol, 2012; 28: 937-942.

75. Pacwa-Płociniczak M, Płaza GA, Poliwoda A, Piotrowska-Seget Z. Characterization of hydrocarbon-degrading and biosurfactantproducing Pseudomonas sp. P-1 strain as a potential tool for bioremediation of petroleum-contaminated soil. Environ Sci Pollut R., 2014; 21(15): 93859395.

76. Parry AJ, Parry NJ, Peilow C, Stevenson PS. Combinations of Rhamnolipids and Enzymes for Improved Cleaning. 2013, Patent no. EP 2596087 A1.
77. Patel RM, Desai AJ. Biosurfactant production by Pseudomonas aeruginosa GS3 from molasses. Letters in Appl. Microbiology, 1997; 25:91-94.

78. Peter J, Singh DP. Characterization of emulsification activity of partially purified Rhamnolipids from Pseudomonas fluorescens, International Journal of Innovation and Scientific Research, 2014;.3(1): 88-100.

79. Piljac T, Piljac G. Use of Rhamnolipids as Cosmetics. 2007, Patent no. EP 1056462 B1.

80. Pimienta ALR, Díaz MMP, Carvajal SFG, Grosso VJL. Production of biosurfactants (rhamnolipids) by Pseudomonas aeruginosa isolated from Colombian sludges, CT\&F-Ciencia, Tecnología y Futuro, 1997; 1(3): 95-108.

81. Praveesh BV, Soniyamby AR, Mariappan C, Kavithakumari P, Palaniswamy M. Lalitha S. Biosurfactant production by Pseudomonas sp. from soil using whey as carbon source, New York Science Journal, 2011; 4(4): 99-103.

82. Prieto LM, Michelon M, Burkert JFM, Kalil SJ, Burkert CAV. The production of rhamnolipid by a Pseudomonas aeruginosa strain isolated from a southern coastal zone in Brazil. Chemosphere, 2008; 71(9): 1781-1785.

83. Priya T, Usharani G. Comparative Study for Biosurfactant Production by Using Bacillus subtilis and Pseudomonas aeruginosa, Botany Research International, 2009; 2(4): 284-287.

84. Puskarova A, Bučková M, Chovanová K, Harichová J, Karelová, E, Godočiková J. Polek B, Ferianc P, Diversity and PAH growth abilities of bacterial strains isolated from a contaminated soil in Slovakia. Biologia. 2013; 4: 587-591.

85. Rahman KSM, Rahman TJ, Kourkoutas Y, Petsas I, Marchant R, Banat IM. Enhanced bioremediation of n-alkane in petroleum sludge using bacterial consortium amended with rhamnolipid and micronutrients, Bioresour Technol , 2003; 90(2):159-68.

86. Rahman KSM, Rahman TJ, McClean S, Marchant $\mathrm{R}$, Banat IM. Rhamnolipid biosurfactant production by strains of Pseudomonas aeruginosa using lowcost raw materials, Biotechnol.Prog. 2002;18:12771281.

87. Rashedi H, Assadi MM, Bonakdarpour B, Jamshidi E. Environmental importance of rhamnolipid production from molasses as a carbon source, Int. J. Environ. Sci. Tech, 2005; 2(1); 59-62.

88. Raza, Z.A., Khan, Z.M., Physicochemical and surface-active properties of biosurfactant produced using molasses by a Pseudomonas aeruginosa mutant, J Environ Sci Health A Tox Hazard Subst Environ Eng. 2007; 42: 72-80.

89. Reis RS, Pacheco GJ, Pereira AG, Freire DMG. Biosurfactants: Production and Applications. In Chamy R, Rosenkranz F., editors.Biodegredationlife of Science. Open Access 2013, p.31-61. 
90. Rikalovic MG, Cvijovic GG, Vrvic MM, Karadzic I. Production and characterization of rhamnolipids from Pseudomonas aeruginosa san-ai. J. Serb. Chem. Soc. 2012; 77 (1); 27-42.

91. Robert M, Mercade ME, Bosch MP, Para J, Espiny MJ, Manresa MA, Guinea J. Effect of the carbon source on biosurfactant production on Pseudomonas aeruginosa 44 T1, Biotechnol Lett, 1989;11: 871874.

92. Rodrigues L, Banat IM, Teixeira J, Oliveira, R. Biosurfactants: potential applications in medicine. $J$ Antimicrob Chemother, 2006; 57(4):609-18.

93. Sahoo S, Datta S, Biswas D. Optimization of culture condition for biosurfactant from Pseudomonas aeruginosa OCD1. JASR, 2011; 2(3): 32-36.

94. Saikia RR, Deka S, Deka M, Banat IM. Isolation of biosurfactant-producing Pseudomonas aeruginosa RS29 from oil-contaminated soil and evaluation of different nitrogen sources in biosurfactant production. Ann Microbiol. 2012, vol. 62, pp. $753-$ 763.

95. Santa Anna LM, Sebastian GV, Pereira NJ, Alves TL, Menezes EP, Freire DM. Production of biosurfactant from a new and promising strain of Pseudomonas aeruginosa PA1, Appl Biochem Biotechnol. 2001; (91-93): 459-67.

96. Santos SC, Fernandez LG, Rossi-Alva JC, Roque MCA. Evaluation of substrates from renewable resources in biosurfactants production by Pseudomonas strains, Afr J Biotechnol, 2010; 9(35):5704-5711.

97. Sekhon Randhawa K, Rahman PKSM. Rhamnolipid biosurfactants-past, present, and future scenario of global market. Front Microbiol, 2014; 5: 454.

98. Sidal U, Kolankaya N, Kurtonur C. Obtaining Biosurfactant from Olive Oil Mill Effluent (OOME) Using Pseudomonas sp. Turk J Biol. 2000;.24: 611625.

99. Silva SN, Farias CB, Rufino RD, Luna JM, Sarubbo LA. Glycerol as substrate for the production of biosurfactant by Pseudomonas aeruginosa UCP0992, Colloids and Surfaces. Biointerfaces, 2010: 79(1): 174-183.

100.Sim L, Ward OP, Li ZY. Production and characterization of biosurfactant from Pseudomonas aeruginosa UW-1, J. Ind. Microbiol. Biotechnol. 1997; 19: 232-238.

101.Soberón-Chávez G, Lépine F, Déziel E. Production of rhamnolipids by Pseudomonas aeruginosa, Appl Microbiol Biotechnol, 2005; 68: 718-725.

102.Sridhar B, Karthik R, Tamil-Venthan M, GopieshKhanna V. Production, Purification and antimicrobial activity of biosurfactants from Saccharomyces cerevisiae and Pseudomonas aeruginosa, IJARP, 2013;3(4):1-7.

103. Straube WL, Nestler CC, Hansen LD, Ringleberg D, Pritchard PJ, Jonesmeehan J, Remediation of polyaromatic hydrocarbons (PAHs) through land farming with biostimulation and bioaugmentation. Acta Biotechnologica, 2003; 2-3:179-196.

104.Syldatk C, Hausmann R. Microbial surfactants, Eur J Lipid Sci Tech, 2010; 112: 615-616.

105.Syldatk C, Lang. S, Matulovic U, Wagner F. Production of four interfacial active rhamnolipids from n-alkanes or glycerol by resting cells of Pseudomonas species DSM 2874, Z Naturforsch C. 1985; 40(1-2):61.

106. Thaniyavarn J, Chongchin A, Wanitsuksombut N, Thaniyavarn, S., Pinphanichakarn, P., Leepipatpiboon,, N. et al. Biosurfactant production by Pseudomonas aeruginosa A41 using palm oil as carbon source, J Gen Appl Microbiol. 2006;52: 215222.

107.Thanomsub B, Pumeechockchai W, Limtrakul A, Arunrattiyakorn P, Petchleelaha W, Nitoda T, Kanzaki H, Chemical structures and biological activities of rhamnolipids produced by Pseudomonas aeruginosa B189 isolated from milk factory waste. Bioresource Technology. 2007; 98:1149-1153.

108.Trummler K, Effenberger F, Syldatk C. An integrated microbial/enzymatic process for production of rhamnolipids and L- rhamnose from rapeseed oil with Pseudomonas sp. DSM 2874, European Journal of Lipid Science and Technology 2003;105(10): 563-571.

109. Van Dyke MI, Couture P, Brauer M, Lee H, Trevors JT. Pseudomonas aeruginosa UG2 rhamnolipid biosurfactants: structural characterization and their use in removing hydrophobic compounds from soil, Can J Microbiol, 1993; 39(11):1071-8.

110. Venkata-Ramana K, Karanth N. Factors affecting biosurfactant production using Pseudomonas aeruginosa CFTR-6 under submerged conditions, J.Chem. Tech. Biotechnol, 1989;45: 249-257.

111. Wana J, Chaia L, Lua W, Lin Y, Zhang S. Remediation of hexachlorobenzene contaminated soils by rhamnolipid enhanced soil washing coupled with activated carbon selective adsorption, J Hazard Mater, 2011;189: 458-464.

112.Wei YH, Chou CL, Chang JS. Rhamnolipid production by indigenous Pseudomonas aeruginosa J4 originating from petrochemical wastewater. Biochem Eng J, 2005; 27: 146-154.

113.Wen SP, McLaughlin MJ, Kirby JK. Biodegradation of rhamnolipid, EDTA and citric acid in cadmium and zinc contaminated soils. Soil Biology and Biochemistry, 2009; 41(10); 2214-2221.

114. Whang LM, Liu PWG, Ma CC, Cheng SS. Application of biosurfactants, rhamnolipid, and surfactin, for enhanced biodegradation of dieselcontaminated water and soil, J Hazard Mater. 2008; 151(1):155-63.

115. Wittgens A, Tiso T, Arndt TT, Wenk P, Hemmerich J, Müller C, et al. Growth independent rhamnolipid production from glucose using the non-pathogenic 
Pseudomonas putida KT2440, Microbial Cell Factories, 2011; 10: 80.

116.Wu JY, Yeh KL, Lin CL, Chang JS. Rhamnolipid production with indigenous Pseudomonas aeruginosa EM1 isolated from oil-contaminated site, Bioresour Technol. 2008; 99: 1157-1164.

117.Xia WJ, Luo Z, Dong HP, Yu L, Cui QF, Bi YQ. Synthesis, characterization, and oil recovery application of biosurfactant produced by indigenous Pseudomonas aeruginosa WJ-1 using waste vegetable oils, Appl Biochem Biotechnol, 2012; 66:1148-1166.
118. Yilmaz ES, Sidal U. Investigation of antimicrobial effects of a Pseudomonas-originated biosurfactant, Biologia -Bratislava, 2005; 60: 723-5.

119.Zhang W, Li, J, Huan G, Song W, Huang Y. An experimental study on the bio-surfactant-assisted remediation of crude oil and salt contaminated soils. J Environ Sci HealthA Tox Hazard Subst Environ Eng., 2011; 46(3): 306-13.

120.Zhang Y, Maier WJ, Miller RM. Effect of Rhamnolipids on the Dissolution, Bioavailability, and Biodegradation of Phenanthrene, Environ. Sci. Technol., 1997; 31(8): 2211-2217.

121.Zhu Y, Gan J, Zhang G, Yao B, Zhu W, Meng Q. Reuse of waste frying oil for production of rhamnolipids using Pseudomonas aeruginosa zju.u1M, Journal of Zhejiang University - Science A. 2007; 8:1514-1520. 